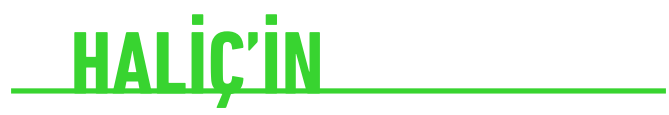

DöNï̄șïmï̈:

\section{KÂĞITHANE VE}

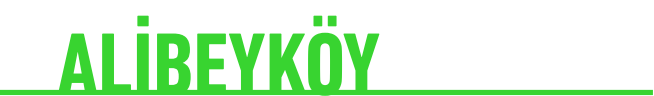

\section{YERLESTIMLERINININ}

DURUMU

\section{Kübra Yaşar*}

Meltem

İzmir Akdeniz Akademisi Derģisi/

Journal of the Izmir Mediterranean Academy

No. 9, Yaz/Summer 2021, 58-76, DOI 10.32325/iaad.2021.4

* İstanbul Teknik Üniversitesi, Mimarlık Bölümü, Araştırma Görevlisi / Istanbul Technical University, Department of Architecture, Research Assistant / ORCID iD https://orcid.org/0000-00027145-9789
18. yüzyılda Lale Deuri ile başlayan batılı yaşam tarzı ile sayfiye ve mesire yerlerine olan ilggi artmış, bunun sonucunda deniz kıyılarında sahilsarayları, yalılar ve köşkler inşa edilmiştir. Bu dönemde Haliç kıyıları da yoğun ilģi gören yerlerden olmuş, Haliç'in gerek kuzey gerekse de güney kıyılarında çok sayıda yalı inşa edilmiştir. 19. yüzyılda Endüstri Deurimi'nin Osmanlı Devleti üzerinde yansımaları görülünce, devlet eliyle veya özel kişi/kuruzmlar tarafından fabrikalar kurulmaya başlanmıştı. Osmanlı başkenti İstanbul'da sanayileşme ģirişimlerinin en yoğun yaşandığı yerler su kıyıları olmuş, bunun sonucunda Haliç'in kuzey ve güney kıyıları da sanayi yapılarının kurulması için tercih edilen alanlar olmuştur. Bu dönemde Haliç kıyılarında çok sayıda üretim tesisi ve bunlara hizmet eden depolar, atölyeler kurulmuş, dolayısıyla Haliç'teki yoğunluk artmış ve kıyılarında hızlı bir dönüşüm yaşanmıştır. Haliç'i besleyen iki dere ve bunların etrafındaki yerleşimlerden Kâs̆ıthane, 16. yüzyıldan itibaren şehzadelerin sünnet düğünlerinin yapıldığı bir hasbahçe olup özellikle Lale Devri'nde önemi artmış ve burada çok sayıda köşk ve kasır inşa edilmiştir. Böylelikle Kâs̆ıthane kentin eğlence merkezi haline gelmiştir. 18. yüzyılda kazandığı "eğlence merkezi" işlevini 19. yüzyılda da sürdürmüş, Haliç'te yaşanan yoğun sanayileşme girişimleri bu kıyılara ulaşmamıştır. Miri arazi olarak kullanılan Alibeyköy ise Kâs̆ıthane'ye göre daha farklı bir dönüşüm göstermiş, bölgede var olan sayfiye işlevinin yanı sıra bir takım sanayi tesisleri de kurulmuştur.

Anahtar Sözcükler: Sanayileşme, Dönüşüm, İşleusel Süreklilik, Sayfiye, Haliç 


\section{A B S T R A C T}

Transformation of the Golden Horn in the $19^{\text {th }}$ Century: The State of Kâğıthane and Alibeyköy Settlements

Since the western life style has affected Ottoman Empire in the $18^{\text {th }}$ century (Tulip Era), the interest in summer resorts and the recreation areas increased. As a result of this, too many coastal palaces, mansions and kiosks were built on the shores of capital city Istanbul. During this period, the shores of the Golden Horn were also places of great interest, and many mansions were built on both the northern and southern shores of the Golden Horn. In the $19^{\text {th }}$ century, when the reflections of the Industrial Revolution on the Ottoman Empire were start, factories were started to be established by the state or by private individuals/institutions. In the Ottoman capital, Istanbul, because entrepreneurs especially choose the seashores, the northern and southern shores of the Golden Horn became the preferred areas for the establishment of industrial structures. During this period, many production facilities and warehouses and workshops were built on the shores of the Golden Horn, so the density in the Golden Horn increased and a rapid transformation took place on its shores. Kâğıthane, one of the two streams feeding the Golden Horn and the settlements around them, is a "hasbahçe" where festivities for the princes (şehzade) were held since the $16^{\text {th }}$ century. Its importance increased especially in the Tulip Era, and many mansions and pavilions were built here. Thus, Kâğıthane has become the entertainment center of the city. It continued its "entertainment center" function, which it gained in the $18^{\text {th }}$ century, in the $19^{\text {th }}$ century, and the intense industrialization attempts in the Golden Horn did not reach these shores. Alibeyköy, which is used as miri land, has undergone a different transformation compared to Kâğıthane, and some industrial facilities have been established in addition to the existing summer resort function in the region.

Keywords: Industrialization, Transformation, Functional Continuity, Countryside, Golden Horn
Osmanlı Devleti için 19. yüzyıl birçok alanda değişim ve dönüşümlerin yaşandığı bir dönem olmuştur. $\mathrm{Bu}$ dönemde Osmanlı Devleti pek çok yenilikle tanışmış ve adeta ithal edilen bu yenilikler özellikle başkent İstanbul ve çevresinde gözle görülür sonuçlar yaratmıştır. $\mathrm{Bu}$ değişiklikler sonucu Osmanlı kurumları yeniden düzenlenmiş, çeşitli nizamname ve düzenlemeler yürürlüğe girmiş, İstanbul kent dokusu "batılı" bir şekle sokulmaya başlanmış, yapılarda ahşap yerine taş ve tuğla gibi malzemeler kullanılmaya bașlanmıș ve hatta kent sakinlerinin kılık kıyafet ve yaşam biçimleri de farklılaşmaya başlamıştır. Kentin dönüşümünde belirgin bir rol oynayan sebeplerden sayılabilecek sanayileşme faaliyetleri 19. yüzyılda önem verilen konulardandır. Sanayi tesislerinin ihtiyaç duyduğu altyapı hizmetleri konusunda kolaylık sağlayan su kıyılarının tercih edilmesiyle kentin kıyı şeridinde yer alan Zeytinburnu, Beykoz gibi bölgeler sanayi tesislerinin kurulmasında tercih edilen bölgeler olmuşlardır. Kentin en önemli bölgelerinden sayılabilecek Haliç çevresinde de sanayileşmenin yoğunlukla yaşandığı gözlemlenmektedir.

Antik dönemlerden beri kentin en önemli bölgelerinden olan Haliç ve yakın çevresi Osmanlı Dönemi'nde de önemini korumuştur. Kentin en önemli limanlarının yer aldığı Haliç, aynı zamanda ticaret faaliyetlerinin yoğunlukla yaşandığı, gemilerin bakım ve onarımlarının yapıldığı bir bölgedir. 17. ve 18. yüzyıllara kadar bu işlevini sürdüren Haliç ve yakın çevresinde, bu tarihlerden sonra mesire alanları oluşmuş, bu bölgeler hem saray halkının hem de kent sakinlerinin tercih ettiği bölgeler haline gelmiştir. Haliç'in güneyinde Fener ve Balat kıyılarında kentin varlıklı ailelerinin yalıları yer alırken, Ayvansaray ve Defterdar bölgeleri 
hanedanın kadın üyeleri tarafından tercih edilmiştir. Haliç̧in kuzeyinde Hasköy ve Sütlüce kıyılarında da sahilsarayları ve yalıların yer aldığı bilinmektedir. 19. yüzyıla gelindiğinde ise Haliç’in kuzey ve güney kıyılarında gıda, sabun, tütün gibi farklı sektörlere hizmet eden çok sayıda üretim ve sanayi tesisi kurulmuştur. Böylelikle Haliç’te var olan sayfiye işlevi yerini zamanla sanayiye bırakmıştır.

Haliç’in 19. yüzyılını inceleyen pek çok kaynak bulunmaktadır. Söz konusu kaynakların büyük bir kısmı yukarıda bahsedilen dönüşümü konu almış, sanayileşmenin nedenlerini araştırmış, bir yerleşim ve sayfiye yeri olan Haliç’e sanayinin gelişinin olumsuzluklarını tartışmıştır. Bunun yanında sanayi tesislerinin belgelenmesi, dokümantasyonu yapılmıştır. Bölgede yaşanan dönüşümün yoğunluğu, konut bölgelerine ve ticarete olan etkisi, kent dokusu ve silüetinin değişimindeki rolü incelenmiştir. Bu tartışmaların içinde Kâğıthane ve Alibeyköy'ün yeri ise yok denecek kadar azdır. Bu iki bölgeyi konu alan çalışmalar çoğunlukla 18. yüzyılı odağına alan ve bu bölgelerde gelişen mimari stiller ile batılı yaşam tarzı üzerine incelemelerdir. Birer Haliç yerleşimi olarak Kâğıthane ve Alibeyköy’ün 19. yüzyıldaki durumları ise az tartışılmış bir konu olarak karşımıza çıkmaktadır.

Bu çalışmanın amacı 19. yüzyılda Haliç’i besleyen iki dere ve bunların etrafındaki Kâğıthane ve Alibeyköy'ün durumunu anlamaktır. Söz konusu köylerin antik dönemlerden beri gösterdikleri gelişim ve bunun paralelinde bölgelerin 19. yüzyılda birer Haliç yerleşimi olarak yer aldıkları konum incelenecektir. Çalışma yürütülürken çoğunlukla birincil kaynaklar üzerinden bir okuma yapılmıştır. Arşiv belgeleri ve dönem yazarlarının yanı sıra fotoğraflar, gravürler ve haritalar gibi çeşitli görsel kaynaklar kullanılarak bölgenin bir resmi çizilmeye çalışılmış ve bu resim üzerinden bir takım cevapların elde edilmesi hedeflenmiştir.

\section{Yüzyıl ve Öncesinde Haliç Kıyılarının Durumu}

Byzantion Dönemi’nde bir liman görevi görmekte olan Haliç, Bizans Dönemi'ne gelindiğinde de kentin en önemli limanları olan Neorion ve Prosphorion limanlarını barındırıyordu. Bu limanların çevresinde depolar, işlikler, gemi bakım ve onarımı ile uğraşan atölyeler yer alıyordu. 10. yüzyıldan itibaren yabancı tüccarlar, Yahudi iş adamları da buraya yerleşme hakkı elde etmişlerdi. Kentteki liman faaliyetleri Neorion Limanı'nın batısına da yayılmış, liman ve Unkapanı arasındaki bölge kentin en yoğun ticaret bölgesi olmuştur. Bizans Dönemi’ndeki diğer bir önemli bölge ise Kasımpaşa koyunda yer alan tersanedir. Askeri ihtiyaçlar nedeniyle kurulan bu tersanede gemi yapım ve bakımı için çok sayıda göz bulunmaktaydı. ${ }^{1}$

Fetihten sonraki dönemlerde de Haliç kentin en önemli limanı olmaya devam etmiş, Bizans Dönemi’ndeki önemli ticaret bölgeleri fetihten sonra da faaliyetlerini sürdürmeye devam etmiştir. Buralarda "kapan" adı verilen pazar binaları kurulmuş, esnaf ve kentin sakinleri için gerekli hammaddelerin satışı sağlanmıştır. İlerleyen yüzyıllarda Haliç kıyılarında kalafat yerleri, gemi bakım atölyeleri, Rum meyhane ve kahvehaneleri ve esnaf dükkânları yer alıyordu. ${ }^{2}$ Haliç

\footnotetext{
1 Wolfgang Müller-Wiener, Bizans'tan Osmanlı'ya İstanbul Limanı, çev. Erol Özbek (İstanbul: Tarih Vakfı Yurt Yayınları, 1998).

2 Müller-Wiener, İstanbul Limanı; Robert Mantran, 17. Yüzyılın Ikinci Yarısında İstanbul: Kurumsal, iktisadi, Toplumsal Tarih Denemesi, c. 2, çev. Mehmet Ali Kılıçbay ve Enver Özcan (Ankara: Türk Tarih Kurumu, 1990).
} 
kıyısındaki sur dışı yerleşkeler kendi üretim faaliyetlerini yaratmış ve kentin ticaret hayatına katkıda bulunmuşlardır.

17. yüzyılda çoğunlukla Rumların ikamet ettiği Fener yakınlarında meyhaneci esnafı yer alırken, Fener’den sonra yer alan Balat Kapısı'nın büyük iskelesi her türlü ürünün getirildiği bir pazar görevi görmekteydi. Ayrıca bu kıyılarda çömlekçilerin, meyhanecilerin ve cambazların yerleşmiş olduğu görülmektedir³. Haliç kıyısında bulunan sur dışı yerleşim bölgelerinin de gelişerek kendi üretim faaliyetlerini yaratmış olduğu ve ticaret hayatına katkıda bulunduğu görülmektedir. Eyüp civarında yapılaşmanın ve nüfusun artması ticaret hayatını da zenginleştirmiş, kıyıda çanak-çömlek imalatı ve ticareti gelişmiştir. Hasköy’deki Piripaşa Köyü’nde kiremit imalathanelerinin bulunduğu ve burada yer alan atölyelerde, dere ağzından çıkarılan çamurdan, tuğla ve kiremit üretimi yapıldığı bilinmektedir. Evliyâ Çelebi'ye göre Piripaşa sahilinde 200 kiremitçi dükkânı bulunuyordu. Burada deniz dibinden çıarılan siyah çamurdan kırmızı renkte tuğla veya kiremit üretilmekteydi. ${ }^{4}$

17. yüzyılda Kasımpaşa ve çevresi tersane işlevini sürdürüyordu, bölgenin çevresinde gemi yapımıyla ilgili imalathaneleri bulunmaktaydı. Evliyâ Çelebi’nin aktardığına göre, Kasımpaşa'da 3.060 dükkân bulunuyordu, özellikle debbağlar esnafı çok kalabalıktı, Kasımpaşa’da bulunan derenin iki tarafında ise dükkanlar sıralanıyordu. Bölgede ayrıca Cumapazarı, Kasımpaşa Çarşısı, Piyalepaşa Pazarı, Terziler Pazarı, Kulaksız Pazarı, Debbağlar Pazarı ve İskele Pazarı gibi pazarlar bulunmaktadır.5

18. yüzyılda Lale Devri ile başlayan batılı yaşam tarzının benimsenmesi ile sayfiye ve mesire yerlerine olan ilgi artmış, bu da deniz kıyılarında sahilsaraylarının, yalıların ve köşklerin inşa edilmesine neden olmuştur. Bu dönemde Haliç kıyıları da yoğun ilgi gören yerlerden olmuş, Haliç’in gerek kuzey gerekse de güney kıyılarında çok sayıda yalı inşa edilmiştir. ${ }^{6}$ Hovhannesyan’a göre, Cibali Kapısı ile Aya Kapısı arasında hem sur içinde hem de sahilde çok sayıda ev yer alıyor, bu evlerde çok sayıda Rum yaşıyordu. Ayakapı'dan Fener ve Balat’a uzanan kıyıda Rum zenginlerinin ve Eflak-Boğdan beylerinin sıra evleri konumlanmaktaydı. ${ }^{7}$ Fener'de 18. yüzyılda Rum aristokrat ailelerin yalıları ve konakları yer almaktaydı. Haliç'in kuzey kıyılarında ise Kasımpaşa ve Sütlüce ağırlıklı olarak Müslümanların yaşadığı semtler iken Hasköy’de 18. yüzyılda Yahudi yerleşkeleri bulunmaktaydı. ${ }^{8}$

Ayvansaray’dan Eyüp’e kadar uzanan kıyılar ise hanedanın kadın üyelerinin sahilsaraylarının ve bu saraylara ait bir takım yapıların inşa edildiği bölgelerdir. Bostancıbaşı Defterleri’nden 1814-15 tarihli bir kayıtta Ayvansaray’ın 18. yüzyılda parlak bir dönem yaşadığı, kıyılarında 19. yüzyılın ilk yarısına kadar birçok yalının bulunduğu anlaşılmaktadır. Buna göre Ayvansaray kıyısında çok sayıda yalı ve kayıkhane yer alıyordu. Ayvansaray Surlarının yakınında, Sultan IV. Mehmet'in

\footnotetext{
3 Mantran, 17. Yüzyılın Ikinci Yarısında İstanbul.

4 Evliyâ Çelebi, Günümüz Türkçesiyle Evliyâ Çelebi Seyahatnâmesi: İstanbul, c. 1, ktp. 1, haz. Seyit Ali Kahraman ve Yücel Dağıı (İstanbul: Yapı Kredi Yayınları, 2003), 374.

5 Evliyâ Çelebi, İstanbul, 1:376-83.

6 Sarkis Sarraf Hovhannesyan, Payitaht İstanbul'un Tarihçesi, çev. Elmon Hançer (İstanbul: Tarih Vakfı Yurt Yayınları, 1997).

7 Hovhannesyan, İstanbul'un Tarihçesi, 22.

8 Gülin Işık Yılmaz, “Haliç Kıyı Şeridinde Sanayileşme ile Ortaya Çıkan Kentsel Dönüşüm” (Doktora Tezi, Yıldız Teknik Üniversitesi, 2008).
} 
kızı Hatice Sultan'ın sahilsarayı bulunuyordu. Sarayın yanında, Saray Hamamı ya da Yalı Hamamı olarak bilinen yapı yer alıyordu. I. Ahmet’in kızı Fatma Sultan'ın yalısı da yine bu kıyıda Yavedud İskelesi'nin yanında bulunuyordu. ${ }^{9}$

18. yüzyılda Eyüp’te de sosyal açıdan önemli değişim ve gelişmeler gözlenmektedir. Kıyılarında özellikle saray çevresinin yalıları yer aldığı Eyüp, sadece kutsal bir yer olmaktan çıkmış, üst sınıfın sıklıkla kullandığı bir seyir ve eğlence yeri olmuştur. Bu kıyıda, Şah Sultan Yalısı, Saliha Sultan Yalısı, Eyyubi Ensari ve Bostan İskeleleri'nden sonra Zeynep Sultan Yalısı, Valide Sultan Yalısı, Şah İsmail Sultan Yalısı bulunuyordu. ${ }^{10}$ Eyüp’ün bir sayfiye işlevi kazanmasında şüphesiz Kâğıthane bölgesinin payı göz ardı edilemez. 16. yüzyılda şehzadelerin sünnet düğünlerinin yapıldığı ve padişahın haremiyle beraber geldiği bir hasbahçe olan Kâğıthane, 17. yüzyıldan itibaren halkın da dinlenme ve eğlenme mekânı olarak kullandığı gözde mesire yeri olmuştur. ${ }^{11}$ Burada IV. Murat'ın yaptırdığı bir hasbahçe, rengârenk laleleriyle meşhur Lalezar Mesiresi ve Kâğıthane Deresi kenarında padişahlara yemek verilen bir ahşap köşk bulunmaktadır. ${ }^{12}$ Lale Devri'nde bölgenin önemi artmış, Kâğıthane Deresi'nin yatağı temizlenmiş ve kentin en önemli mesire yeri oluşmuştur. Miri arazi olarak kullanılan Alibeyköy ise Kâğıthane’ye göre daha sakin bir bölge olmasına karşın burada da sayfiye işlevi gözle görünür hale gelmiştir. Bu dönemde Alibey Köyü yakınlarında çeşmeler ve kasırlar inşa edilmiştir.

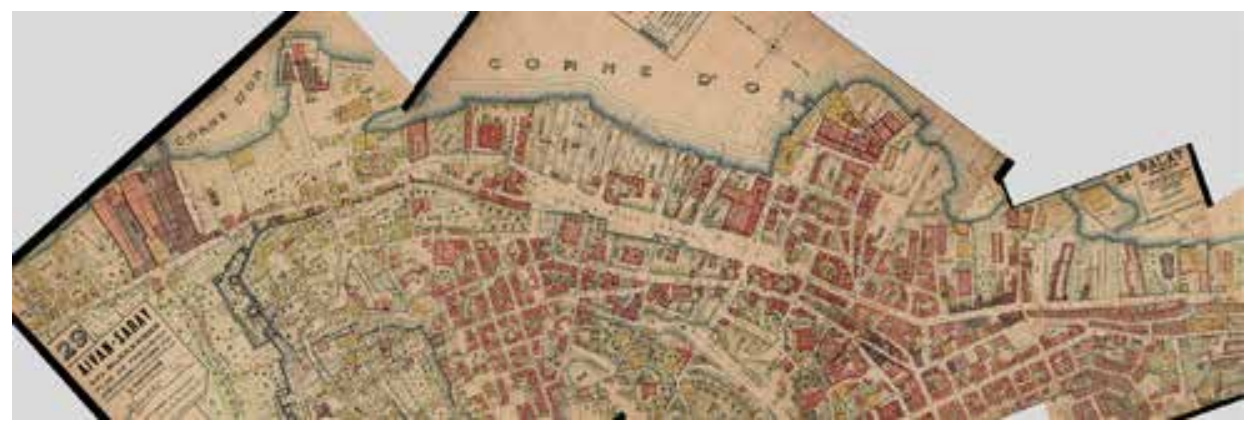

Şekil 1 Haliç'in güney kıyılarında (Ayvansaray-Fener arası) yer alan sanayi tesisleri.

Pervititch Haritaları kullanılarak oluşturulmuştur.

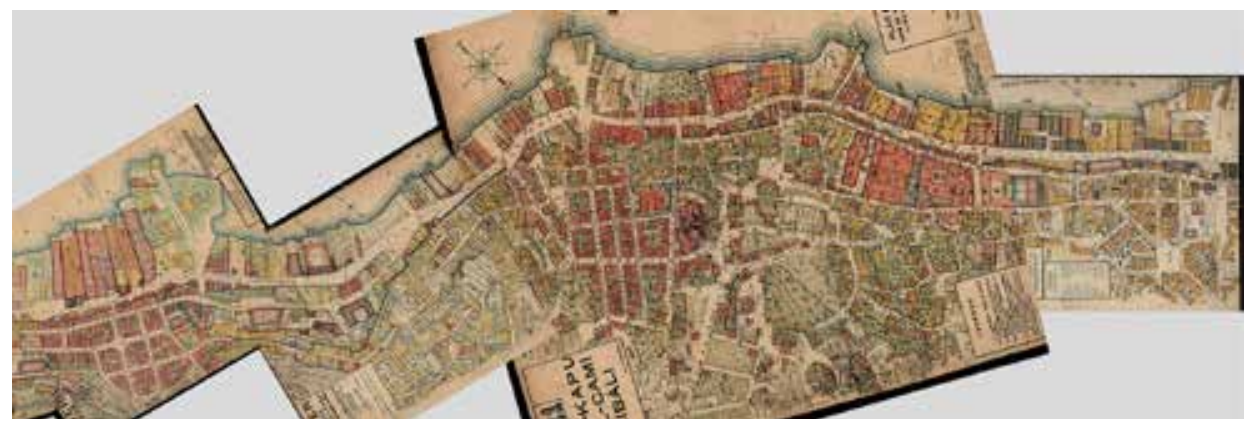

Şekil 2 Haliç'in guüney kıyılarında (Fener-Cibali arası) yer alan sanayi tesisleri.

Pervititch Haritaları kullanılarak olușturulmuştur.

9 Reşad Ekrem Koçu, “Bostancıbaşı Defterleri,” İstanbul Enstitüsü Mecmuası, s. 4 (1958).

10 Hovhannesyan, İstanbul'un Tarihçesi, 71.

11 Eremya Çelebi Kömürciyan, İstanbul Tarihi: XVII. Asırda İstanbul, çev. Hrand D. Andreasyan, 2. bas. (İstanbul: Eren Yayıncılık ve Kitapçılık, 1988), 31.

12 Evliyâ Çelebi, Günümüz Türkçesiyle Evliyâ Çelebi Seyahatnâmesi: İstanbul, c. 1, ktp. 2, haz. Seyit Ali Kahraman ve Yücel Dağlı (İstanbul: Yapı Kredi Yayınları, 2003), 441-43. 
18. yüzyılda sahilsarayları ve yalıların yer aldığı Haliç kıyıları, 19. yüzyılda bu işlevini kaybetmiştir. Bu dönemde özellikle başkent İstanbul'da yoğun bir sanayileşme faaliyetleri başlamış, su kıyıları ulaşım kolaylığı ve güç kaynağı sağladığı gerekçeleriyle özellikle tercih edilmiştir. Böylece Haliç'in gerek kuzey ve güney kıyılarında hem devlet eliyle hem de özel kişi ve kurumlarca işletilen bir takım sanayi ve üretim yapıları kurulmuştur (şek. 1 ve şek. 2).

Haliç'in kuzey kıyısında Kasımpaşa'da yer alan Tersane-i Amire burada yer alan ve devletin işlettiği en eski kuruluştur. Fatih Dönemi’nden beri varlığını sürdüren tersane bölgesinde, I. Abdülhamit Dönemi’nde (1774-1789) depolar ve gemi kalafat yerleri ile Kalyoncular Kışlası inşa edilmiştir. Aynı dönemde tersane bünyesinde meslek okulları kurulmuş, 1776 yılında "Hendese Odası” adıyla bir sınıf açılmıştır.13 Tersane çevresinde kent ve donanma halkına hizmet veren un ve tahıl ambarları yer almaktaydı. Kasımpaşa'da yer alan diğer bir fabrika ise Pilitas Mahdumları ve Madencidis Biraderler tarafından işletilen un fabrikasıdır. Fabrika bünyesinde beş katlı değirmen, iki katlı buğday deposu ve dört katlı kepek ambarı bulunmaktadır. ${ }^{14}$

18. yüzyllda, III. Ahmed Dönemi'nde (1703-1730) inşa edildiği bilinen Lengerhane-i Amire, tersane bölgesine yakın bir konumda Hasköy'de kurulmuştu ve lenger (çapa) üretimi yapmaktaydı. Hasköy'de kurulan bir başka sanayi tesisi, Haliç kıyısındaki önemli tersanelerden biri olan Şirket-i Hayriye Tersanesiydi. 1861'de şirketin kendi vapurlarının bakım ve onarımı için kurulan tersane küçük depo binaları ve üç katlı bir atölyeden oluşuyordu. 1884 yllında tersaneye 45 metre uzunluğunda bir ahşap kızak eklenmişti. ${ }^{15}$ Ayrıca, padişah Abdülmecit’in 1851 yılına ait bir iradesiyle, Hasköy’de eski bir değirmen yıkılıp, yerine buharlı bir değirmen inşa edilmiştir. ${ }^{16} 1815$ yılına ait Bostancıbaşı Defterleri'nde Sütlüce kıyılarında şalope ${ }^{17}$ kayıkhanelerinin yer aldığı ve iskelenin yanında Kormoz adında bir gayrimüslimin işlettiği bir değirmenin varlı̆̆ı anlaşılmaktadır. Döneme ait çeşitli haritalardan da Sütlüce kıyılarında Tapa Fabrikası, Kamondo Fabrikası, 1882'de kurulan Şahbaz Agiya Tuğla Fabrikası ile tuğla fabrikalarının ve tuğla harmanlarının yer aldığı görülmektedir.

Haliç'in güney kıyısında yer alan Eyüp, 19. yüzyıldaki sanayi atılımlarından en erken etkilenen bölgelerdendir. Eyüp Bahariye’de yer alan ve 1827'de üretime başlayan İplikhane-i Amire, ucuz iplik sağlamak amacıyla kurulmuştu ve aynı zamanda Tersane-i Amire için halat üretimi de yapıyordu (Müller-Wiener 1998, 74). Yine Eyüp’te Defterdar İskelesi'nin yanında bulunan arsada 1833 yılında inşa edilen Feshane-i Amire, 19. yüzyılın başlarında kurulan, Asakir-i Mansure-i Muhammediye isimli orduya mensup tüm askerlerin fes ihtiyacını karşılamak üzere kurulmuştu. Fabrikaya 1843’te İngiltere, Fransa ve Belçika'dan buhar makinası getirilmiş, 1895’te ise bünyesinde Feshane’ye çırak yetiştirmek üzere bir sıbyan mektebi açılmıştır. ${ }^{18} 1913-15$ sanayi istatistiklerine göre, Bahariye'de 1912 yllında kurulan Yaşarzade Hasan Hüsnü Efendi Tuğla

13 İsmail Hakkı Uzunçarşılı, Osmanlı Devletinin Merkez ve Bahriye Teşkilâtı, 3. bas. (Ankara: Türk Tarih Kurumu, 1988), 470-507.

14 Osmanlı Sanayii 1913, 1915 Yılları Sanayi İstatistiki, haz. A. Gündüz Ökçün (Ankara: T.C. Başbakanlık Devlet İstatistik Enstitüsü, 1997), 43.

15 T. Gül Köksal, “istanbul'daki Endüstri Mirası için Koruma ve Yeniden Kullanım Önerileri” (Yayımlanmamış Doktora Tezi, İstanbul Teknik Üniversitesi, 2005), 79-80.

16 Adnan Giz, “Türkiye'de İlk Buhar Makineleri," İstanbul Sanayi Odası Dergisi, s. 57 (Kasım 1970): 6-7.

17 On iki topu olan, ambarsız, iki direkli, yirmi yedi zirâ uzunluğunda bir yelkene sahip, küçük, eski bir savaş gemisi.

18 Köksal, “istanbul'daki Endüstri Mirası,” 59. 
Fabrikası bulunmaktadır. ${ }^{19}$ Alman Mavileri'nde bu bölgede Kontrplak fabrikası, fişekhane ve bir Lastik fabrikası görülmektedir. Ayrıca Defterdar'da Yusuf Ziya Efendi Zamklı Pamuk Fabrikas1 yer almaktadır. ${ }^{20}$ Bölgede yer alan bir değirmenin genişletilmesiyle 1864 yllında kurulan ve George Baker tarafından işletilen İttihat Değirmencilik Anonim Şirket-i Osmaniye adlı un fabrikası Ayvansaray'da yer alıyordu. Bu kıyıda ayrıca Rumeli demiryolları müteahhidi Mr. Keith'e ait bir kereste fabrikası, Mösyö La Fontaine ve ortakları ile Aris ve ortaklarına ait iki ayrı sabun fabrikası ve Ermys Konserve Fabrikası yer alıyordu. ${ }^{21}$ Balat'ta 1911'de kurulan Hamiz Karbon ve Osmanlı Anonim Şirketi isimli mürekkep fabrikası bulunuyordu. ${ }^{22}$ Haliç kıyısında yer alan bir diğer sanayi tesisi de Cibali Tütün Fabrikası’ydı. Alexandre Vallaury tarafından tasarlanan ve mimar Hovsep Aznavur tarafından inşa edilen yapı 1884 yılında üretime başlamıştı. Tütün işleme, sigara imalatı yapılan fabrikanın işletmesi, kısa adı Reji (Memalik-i Şahane Duhanları Müşterekül Menfaa Reji İdaresi) olan şirkete verilmişti. 1858 de inşa edilen Corpi Demonsten Un Fabrikası da yine Cibali'de yer alıyordu. ${ }^{23}$ II. Mahmut Dönemi'nde ordu için buharlı bir un değirmeni inşa edilmiş, yapının strüktürü İngiltere'de dökme demirden üretilerek, 1841'de gemiyle İstanbul'a getirtilerek Unkapanı'nda yerinde kurulmuştur. ${ }^{24}$ Pervititch haritalarında, Unkapanı sahilinde kereste depoları, ambar ve dükkânların yer aldığı görülmektedir. Eminönü’ndeki 1908'de üretime başlayan Sabuncuzade Şakir ve Mahdumları adlı sabun fabrikası da Haliç̧in güneyinde yer alan bir diğer sanayi tesisidir.

Bu tesislerin dışında 19. yüzyıldan 20. yüzyıl başlarına kadar Haliç kıyısında yer alan ve haritalardan tespit edilebilen çok sayıda yapı mevcuttur. Eminönü’nde Balıkpazarı civarında çok sayıda balıkhane ve bunlara hizmet eden depolar, iki çikolata fabrikası, bir mum fabrikası ve bir de konserve fabrikası ile Odunkapı'da iki adet makarna fabrikası yer alıyordu. Ayrıca kıyıda çok sayıda kereste dükkânı ve depoları ile sabun ve çikolata fabrikası bulunuyordu. Keresteciler Caddesi olarak bilinen caddenin kuzeyinde büyük sebze-meyve halleri ve bunlara bağlı depolar mevcuttu. Ayrıca Tahtakale'de şeker fabrikaları, Unkapanı'nda tahin fabrikası, çok sayıda kereste deposu ve değirmen; Cibali’de, bir kutu fabrikası, tütün ve kereste depoları, sabunhaneler, bir yağ fabrikası ve un değirmenleri; Fener kıyılarında bitkisel yağ üretimi yapan bir fabrikanın yanı sıra, Nektar ve Bomonti Bira Fabrikası; Fener İskelesi'nden Balat İskelesi'ne kadar uzanan kıyıda ise çok sayıda meyhane, tütün depoları, gümrük depoları, sabun fabrikası, soğuk hava depoları, bir şeker deposu, İş Bankası'na ait bir depo binası ve çok sayıda işlik yer alıyordu. Pervititch haritalarına göre kıyıda Bulgar Kilisesi'nin yakınında bir sandalye fabrikası, tütün deposu, bir soda fabrikası, iki un değirmeni, bir karbonat fabrikası, Süreyya Paşa’nın yün ipliği işliği, bir dokuma imalathanesi ve çok sayıda kayıkhane mevcuttu.

Görüldüğü üzere 19. yüzyılda sanayileşme sonrası Haliç’te yoğunluk sürekli artmış, Haliç kıyıları çok sayıda fabrika, işlik, depo ve bunlara hizmet eden yapıların inşasına sahne olmuştu. Öte yandan şimdiye kadar kayıklarla sağlanan taşımacılık, kayık sayısının artmasıyla yürütülemez

\footnotetext{
19 1913, 1915 Yılları Sanayi İstatistiki, 74.

20 Köksal, “İstanbul'daki Endüstri Mirası,” 245.

21 Kübra Yaşar, "19. Yüzyılda Bır Halıç Yerleşımı Olarak Ayvansaray” (Yüksek Lisans Tezi, İstanbul Teknik Üniversitesi, 2017), 89-96.

22 1913, 1915 Yılları Sanayi İstatistiki, 194.

23 Köksal, “istanbul'daki Endüstri Mirası,” 48

24 Köksal, “İstanbul'daki Endüstri Mirası,” 57.
} 
hale gelmiş ve deniz ulaşımında daha verimli çözümler arayıșına yol açmıştı. Bunun sonucunda 1851'de deniz ulaşımını geliştirecek bir şirketin kurulması gerekliliği ön plana çıkmış ve Bilezikçiyanlar’nn da desteğiyle ilk Osmanlı vapur şirketi olan Şirket-i Hayriye kurulmuştu. Başlarda sadece Boğaz’da işleyen vapurlar 1888 yılında çıkan bir nizamname sonucunda Eminönü-Haliç köyleri arasında işlemeye başlamıştı. Haliç’te ulaşımı kolaylaştıracak bir başka çözüm ise köprülerdi. Haliç’teki ilk köprü 1836'da Azapkapı ve Unkapanı arasında kurulmuştu. O dönemde kentin yoğun ticaret bölgesi ve tersane arasında bağlantı sağlanmış oluyordu. 1838'den sonra Galata'nın hızlı bir şekilde gelişmesi ve nüfusu artan bir ticaret merkezi haline gelmesi ise başka köprüleri gerekli kılmıştı. Böylece, ilk Galata Köprüsü olarak bilinen ve Karaköy ile Eminönü arasındaki bağlantıyı sağlayan ikinci köprü 1845 ’te kuruldu. ${ }^{25}$ Haliç’teki üçüncü köprü ise 1852 'de Ayvansaray ve Piripaşa arasında inşa edildi. ${ }^{26}$

Haliç kıyıları, Byzantion Dönemi'nden beri liman faaliyetlerinin yürütüldüğü ve buna bağlı olarak da ticaretin geliştiği bir bölge olmuştur. Osmanlı Dönemi’nde bu işlev sürdürülmüş, Haliç, kentin en önemli limanı olmaya devam etmiştir. 17. yüzyıla dek Haliç’te gelişerek devam eden ticaret faaliyeti 18. yüzyılda yerini sayfiye işlevine bırakmıştır. Fakat 19. yüzyılda sanayi tesislerine duyulan ihtiyacın artmasıyla, yüzyılın ortalarından itibaren bölge hızlı bir biçimde sanayileşmeye başlamıştı. 1840’lardan itibaren Haliç kıyılarında önce devletin kurup işlettiği bazı fabrikalar kurulmuş, yüzyılın son çeyreğinde ise özel sanayi tesisleri kurulmaya başlanmıştı. Bölge hiçbir zaman bir sanayi yerleşkesi olarak tasarlanmamıştı. Burada yer alan fabrikaların birçoğu çevrelerindeki tesislerden bağımsız inşa edilmişti. Fakat inşa edilen yapıların birbirini desteklediği, ihtiyacı olan hammadde ya da enerjiyi yakınlarında kurulan tesislerden sağladığı söylenebilir. Önceleri küçük çaptaki üretim tesisleri olarak karşımıza çıkan bu yapılar zamanla büyük sanayi tesislerine dönüşmüş ve özellikle sur dışındaki bölge zamanla sanayi bölgesine dönüşmüştür. Öte yandan Şirket-i Hayriye'nin kurulması ve Haliç üzerinde inşa edilen köprüler, bölgeyi altyapı sorunları çözülmüş ve sistemli bir şekilde işleyen bir sanayi bölgesine dönüştürme çabaları olarak da görülebilir. Tüm bunlara ek olarak Haliç kıyılarının demografik yapısında farklılıkların yaşandığı ve kullanıcılarının değiştiğini düşünmek yanlış olmaz. Bu bölgede yaşayan yüksek gelirli kesimin kentin başka bir bölgesine taşındığı ve düşük gelirli olan ve önceleri kayıkçıllk, balıkçılık, hamallık, bahçıvanlık gibi işlerle uğraşan kesimin ise yeni kurulan sanayi tesislerinin iş gücünü oluşturduğu düşünülebilir. Nitekim pek çok kaynak Fener, Balat gibi bölgelerde yaşayan zenginlerin Pera’ya göç ettiğini doğrulamaktadır. ${ }^{27}$ Dolayısıyla Haliç’te kentsel dokudaki dönüşümün yanı sıra demografik bir dönüşümden bahsetmek de mümkün olabilir.

\footnotetext{
25 Zeynep Çelik, 19. Yüzyılda Osmanlı Başkenti Değişen İstanbul, çev. Selim Deringil (İstanbul: Türkiye İş Bankası Kültür Yayınları, 2015), 116-17.

26 “Journal de Constantinople," SALT Araştırma, Erişim Tarihi: 24 Temmuz 2021, https://archives.saltresearch.org/ handle/123456789/129385.

27 Çelik, Değişen İstanbul.
} 
19. yüzyılda Endüstri Devrimi’nin Osmanlı Devleti üzerinde yansımaları görülmeye başlanmış ve bu dönemde gerçekleştirilen sanayileşme faaliyetleri özellikle Haliç kıyılarında büyük bir dönüşüme sahne olmuştur. Bu bölümde birer Haliç yerleşimi olarak kabul edebileceğimiz Kâğıthane Köyü ve Alibey Köyü’nün bu dönüşüm içindeki yeri incelenecektir. Haliç’te yaşanan bu hızlı dönüşümde Kâğıthane Deresi kıyıları belki de bu durumdan en az etkilenen bölge konumundaydı. Alibey Deresi çevresi için ise durum biraz daha farklı gelişecekti.

\section{Kâğıthane Deresi ve Yakın Çevresi}

Antik kaynaklarda ismine rastlanan Kâğıthane (şek. 3), Dionysios'un anlattığına göre Barbyzes Deresi (Kâğıthane) kenarında kurulmuş Pissa isimli bir yerleşkedir. Yine Dionysios’a göre Byzantion’un kurucusu Byzas burada doğmuştur. Kenti, Barbyzes ve Kydaros (Alibey) derelerinin birleştiği yerdeki kutsal alanda kurmaya karar veren Byzas, tanrılara adadığı kurbanlardan birinin bir kartal tarafından buradan alını bugünkü Sarayburnu’na götürülmesiyle, bunun Apollon'dan gelen bir işaret olduğuna inanarak kenti Sarayburnu'na kurar. ${ }^{28}$

Başlangıçta dere kenarında küçük bir köy olan Kâğıthane'de Bizans Dönemi’nde kağıt atölyeleri olduğu bilinmektedir. Bu kağıt üretim işlikleri Osmanlı zamanında da devam etmiş ve köyün Pissa olan ismi “Kâğıthane”ye çevrilmiştir. Evliyâ Çelebi'nin aktardığına göre bu köyde bir cami, bir hamam, yirmi dükkân ve iki yüz hane vardır. ${ }^{29}$

Fetihten sonra buradaki otlaklar sarayın hayvanları için ayrılmış, Mîrâhûr olarak isimlendirilen görevli burada konumlandırılmıştır. Kâğıthane Deresinin Haliç ile buluştuğu bölgede yer alan Mîrâhûr Kasrı (İmrahor Kasrı) beylik otlaklarının idari işlerinin yürütüldüğü ve Mîrâhûr’un konakladığı bir köşk olarak inşa edilmiştir. Kimi kaynaklar bu kasrın ilk kuruluşunu Kanuni Sultan Süleyman dönemine tarihlendirir. Balıkhane Nazırı Ali Rıza Bey’in anlattığına göre, çok süslü bir ahşap köşk olan İmrahor Kasrında, bahar aylarında padişahın da katıldığı kırk gün süren ziyafetler veriliyordu. ${ }^{30}$ Söz konusu şenlikler bölgenin sayfiye yeri olarak kullanılmaya başlamasının ilk adımları olarak görülebilir.

16. yüzyılda şehzadelerin sünnet düğünlerinin yapıldığı ve padişahın haremiyle beraber geldiği bir hasbahçe olan Kâğıthane Deresi kıyıları, 17. yüzyıldan itibaren halkın da gözde mesire yeri olmuştur. ${ }^{31}$ Evliyâ Çelebi’nin aktardığına göre burada IV. Murat'ın yaptırdığı bir hasbahçe, rengârenk laleleriyle meşhur Lalezar Mesiresi ve Kâğıthane Deresi kenarında padişahlara yemek verilen bir ahşap köşk bulunmaktadır. ${ }^{32}$

\footnotetext{
28 Dionysios Byzantios, Boğaziçi'nde Bir Gezinti, çev. Mehmet Fatih Yavuz (İstanbul: Yapı Kredi Yayınları, 2010).

29 Evliyâ Çelebi, İstanbul, 1:443.

30 Seyahatnamelerde Kâğıthane, haz. Hüseyin Irmak ve Rıfat Behar, çev. Mario Veris (İstanbul: Kâğıthane Belediyesi, 2019), 224.

31 Kömürciyan, i̇stanbul Tarihi, 31.

32 Bu noktada hasbahçe ve mesire kelimeleri arasındaki farkın ortaya konması önemlidir. Hasbahçe sultana ya da saraya ait bahçelere verilen addır. Söz konusu bahçeler hanedan üyeleri tarafından eğlenmek ve dinlenmek üzere kullanılmaktadır. Mesire kelimesi ise "gezilip dolaşılacak yer" anlamına gelmektedir. Bu yerler ise halkın yani tebaanın kullanımına açıktır.
} 


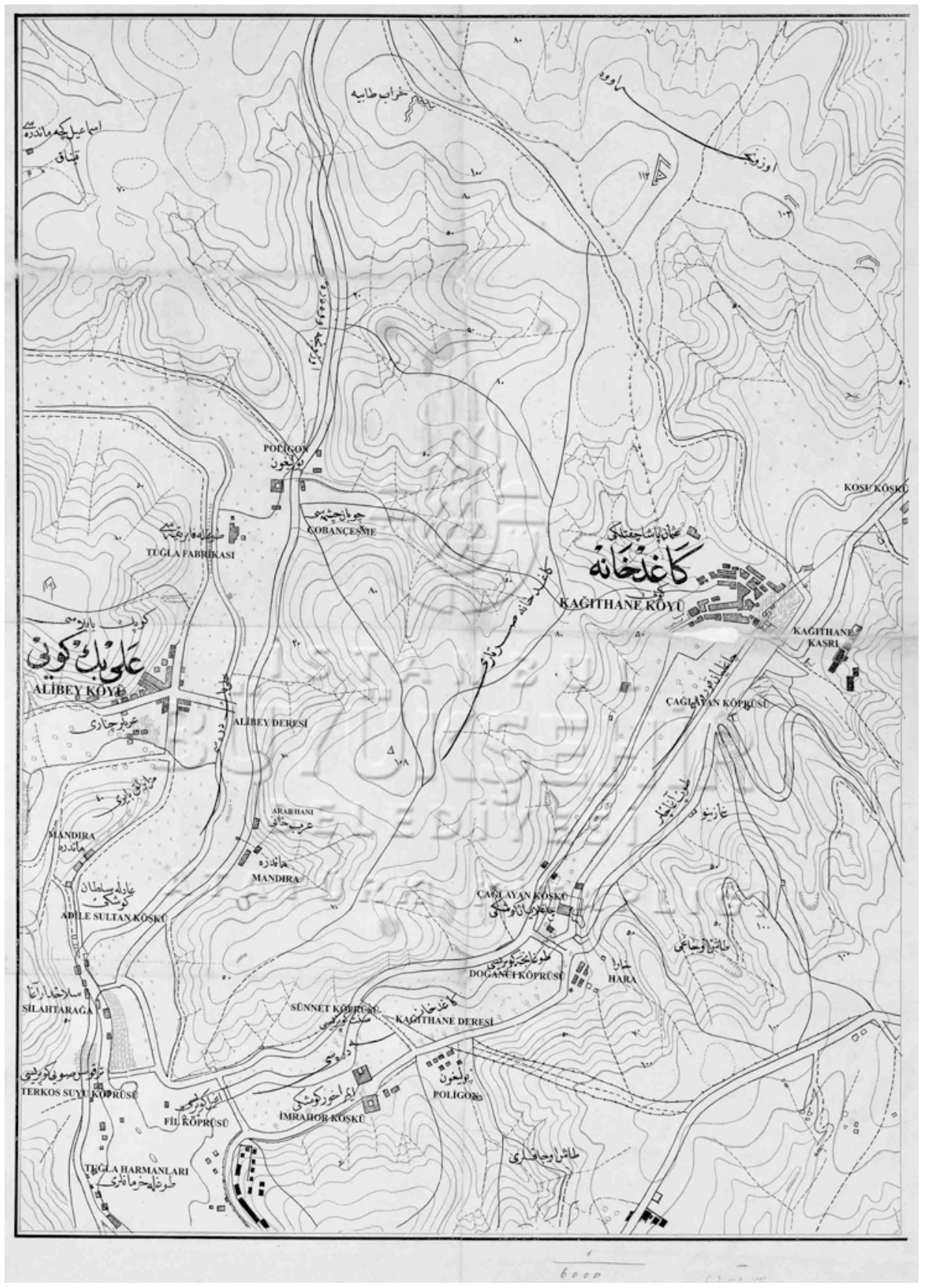

Şekil 3 Kâğıthane-Alibeyköy Haritası, XIX. yüzyıl. Atatürk Kitaplı̆̆ı. Transkripsiyon yazar tarafından yapılmıştır.

18. yüzyılda Lale Devri itibarıyla bölgenin önemi artmış, Kâğıthane kıyıları kentin en önemli mesire yerine dönüşmüştür. Paris elçisi Yirmisekiz Mehmet Çelebi, on bir ay süren Fransa seyahati ve sonrasında sunduğu "Paris Sefaretnamesi” başlıklı raporda Fransa'da gördüğü saray ve bahçe düzenlemelerini anlatmıştır. Gördüklerinden çok etkilenen Çelebi, İstanbul'a döndüğünde Nevşehirli Damat İbrahim Paşa’ya bu sarayların bir benzerinin de İstanbul'da yapılmasını önerir. Padișah III. Ahmet'in de onay vermesiyle Kâğıthane bölgesinde inșa edilmek üzere bir sarayın yapılmasına karar verilmiştir. Sarayın planları ve çevre düzenlemeleri ise Fransa'daki örnekle- 
re benzetilerek yapılmıştır. ${ }^{33}$ Saray başmimarı Kayserili Mehmet Ağa'nın görevlendirildiği proje 1723 yılında tamamlanır. Kâğıthane Köyü’nden itibaren dere yatağı düzenlenmiş ve 1.100 metre uzunluğunda bir kanal inşa edilmiştir. Bu kanala Cetvel-i Sim adı verilir. Kanal üzerinde çeşitli su oyunları için bentler yapılmış ve kanalın bittiği yere bir büyük havuzla sonradan Sâdâbâd ismi verilen saray inşa edilmiştir. Sarayın çevresinde küçük köşk ve kasırlar ile çeşmeler bulunmaktadır. ${ }^{34} \mathrm{Bu}$ inşa faaliyetlerine ek olarak Yoros, Şile ve çevre ormanlardan ıhlamur, karaağaç, kestane, çınar ve dişbudak ağaçları getirilip sarayın çevresine dikilmiştir. ${ }^{35}$

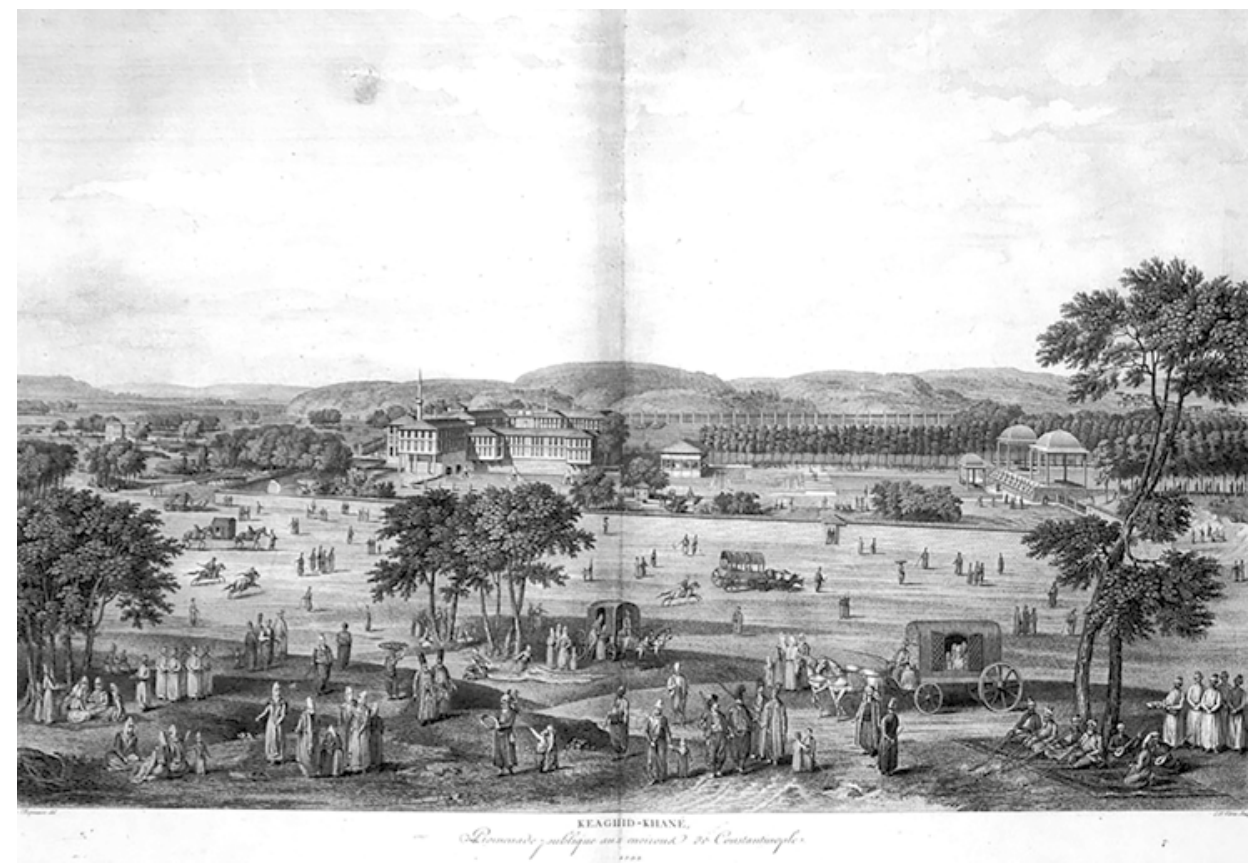

Şekil 4 Kâğıthane, 1740. Ig̣natius Mouradgea d'Ohsson.

28 Eylül 1730'da Patrona Halil İsyanı olarak bilinen ayaklanma sırasında Sâdâbâd Sarayı ve çevresindeki köşkler tahrip edilmiş ve kullanılamaz hale gelmişti. Tahta yeni çıkan I. Mahmut, ayaklanmadan on yıl sonra 1740 yılında Sâdâbâd Sarayı ve etrafındaki köşkleri tamir ettirmiş ve çeşitli düzenlemeler yaptırmıştır. Aynı yıl burada Alman büyükelçisi için bir ziyafet verilmiştir. Bu ziyafetin verildiği, bir bölümü suyun içinden yükselen sütunlar üzerine kurulan saray bazı gravürlerde görülmektedir (şek. 4). Bölgede iskân çalışmaları da yapılmış ve yerleşimi teşvik etmek amacıyla yine I. Mahmut zamanında burada yapı inşa edecek olanlara vergi indirimi ve arazi kolaylığı sağlanmıştır. ${ }^{36}$ Bu dönemde Sâdâbâd Sarayından Haliç’e kadar uzanan arazide aralarında üst düzey yöneticilerin de köşkleri bulunan 173 köşk inşa edilmişti.

19. yüzyılda Kâğıthane Köyü ve Haliç arasındaki bölgede sayfiye işlevi devam ediyordu. 1808 yılında burada gerçekleştirilen bir toplantı sonrasında Sâdâbâd Kasrı padişahın isteği üzerine yıktırılır. 1809 yılında ise Saray başmimarı Krikor Balyan'a yeni bir kasır projesi hazırlatılır. Saray, cami, çeşmeler ve çağlayanların da yeniden inşa edildiği kompleksin yapımı 1816 yılında

\footnotetext{
33 Ilk Çağdan Günümüze Kâğıthane, c. 2, haz. Hüseyin Irmak (İstanbul: Kâğıthane Belediyesi, 2018), 648.

34 Sedad Hakkı Eldem, Sa'dabad (Ankara: Kültür Bakanlığı, 1977), 7-9; ilk Çağdan Günümüze, 2:648.

35 BOA, IE.DH, 35/3062, 1723; C.SM, 135/6775, 1723; C.BLD, 21/1018, 1723.

36 BOA, AE.SMHD.I, 33/1970, 1728.
} 


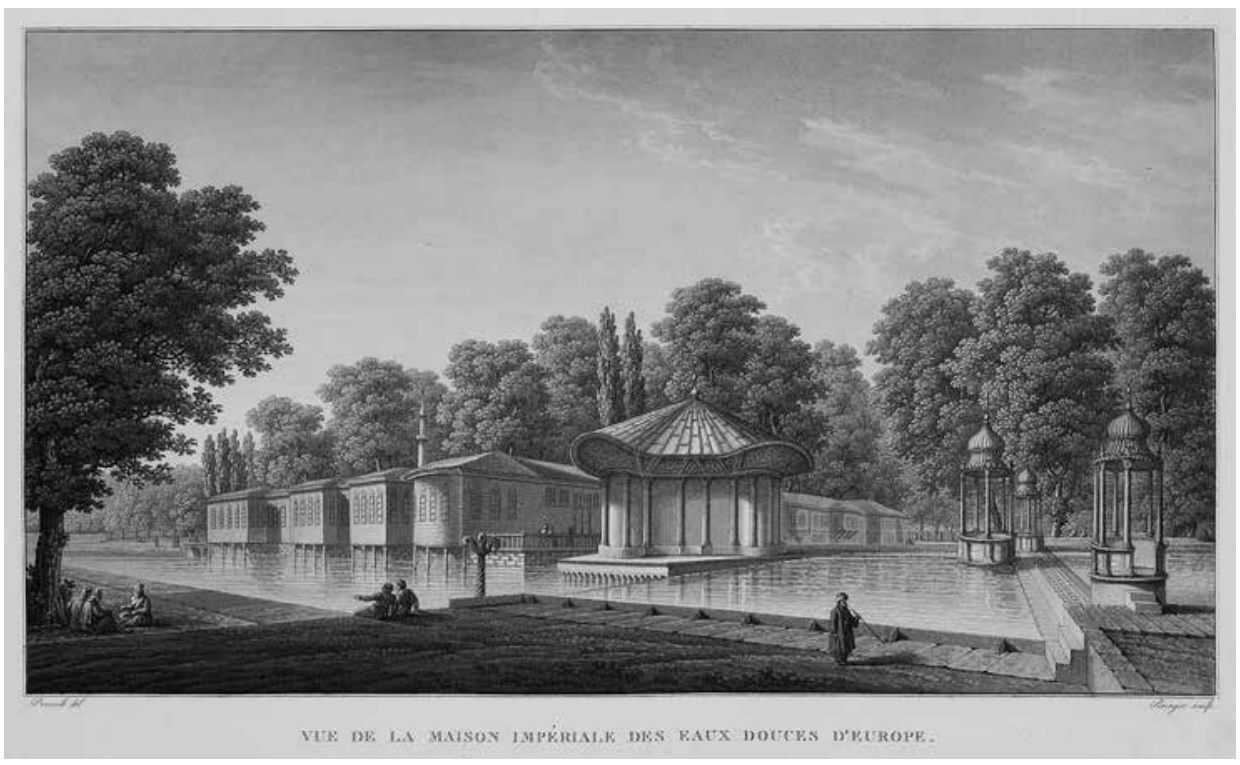

tamamlanır. Dönemin gezginlerinin hatıratlarında sıkça rastlanan ahşap saray II. Mahmud tarafından sıkça kullanılmıştır (şek. 5). ${ }^{37}$ Abdülaziz dönemine gelindiğinde II. Mahmud tarafından yaptırılan saray çok küçük olduğu ve gerekli salonları bulundurmadığı gerekçeleriyle yıktırılmış ve 1862 yllında yerine daha büyük görkemli bir ahşap saray inşa edilmiştir. Üçüncü Sâdâbâd Sarayı ya da Çağlayan Kasrı olarak bilinmektedir. Sarkis Balyan tarafından dönemin mimari akımları gözetilerek inşa edilmiş olan bu saray 79 odalıdır (șek. 6). ${ }^{38}$ Bu dönemde İmrahor Kasrı da yenilenmiştir. 1941 yılına kadar ayakta kalan Çağlayan Kasrı II. Meşrutiyet sonrasında bir süre yetimhane olarak kullanılmış, bu süreden sonra ise sık sık el değiştirmiştir. 1950 yılında ise arazisi Milli Savunma Bakanlığı’na devredilmiştir. ${ }^{39}$ Eldem’in aktardığına göre Abdülaziz Dönemi’nde Kâğıthane bölgesinde iki başka köşk daha inşa edilmiştir. Bunlardan ilki Kâğıthane köyü karşısında yer alan ve II. Mahmud'un kızı Atiye Sultan için inşa edilen Kâğıthane Kasrı Hümayunu'dur (şek. 7). Diğeri ise köyün biraz daha ilerisinde Kâğıthane deresinin karşısında yer alan Koşu Köşkü'dür (şek. 8). Burada at yarışları düzenlendiği bilinmektedir. ${ }^{40}$ Her iki yapının planları ve Kâğıthane’nin 19. yüzyıldaki durumu Eldem tarafından 1977 yılında yayımlanmıştır (şek. 9). ${ }^{41}$

18. yüzyılın sonlarında Kâğıthane'de bir topçu okulunun kurulduğu ve Cebehane-i Amire'den gelen mühimmat ile burada talim yapıldığı anlaşılmaktadır. Söz konusu okulun 110 öğrencisi vardır. ${ }^{42} 1774$ tarihinde, Macar asıllı Fransız subay ve diplomat Baron François de Tott burada eğitim vermek üzere görevlendirilmiştir. ${ }^{43}$ II. Abdülhamid Dönemi’nde Kâğıthane ve Çobançeşme poligonları yenilenmiş, Kâğıthane Poligonu'nun yanına bir kasır inşa edilmiştir. ${ }^{44}$

37 Eldem, Sa'dabad, 74-75.

38 Eldem, Sa'dabad, 93.

39 Illk Çağdan Günümüze, 2:660-62.

40 BOA, Y.PRK.HH, 6/29, 1884.

41 Eldem, Sa'dabad, 118-19.

42 BOA, C.AS, 49992, 1772.

43 İlk Çağdan Günümüze, 2:590.

44 Ilk Çağdan Günümüze, 2:598. 


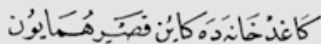

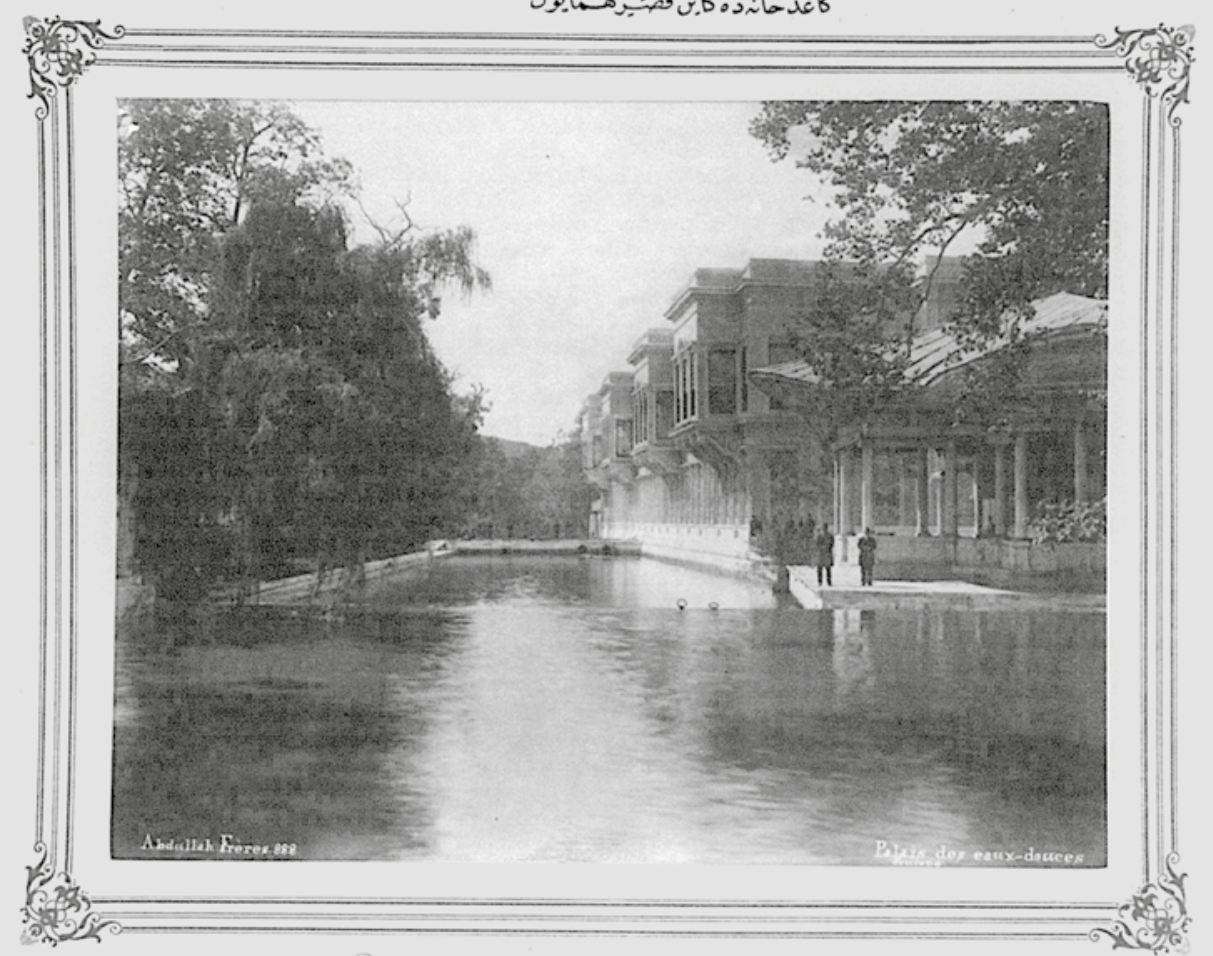

Şekil 6 Çağlayan Kasrı, XIX. yüzyıl. Sultan II. Abdülhamid Han'ın Yıldız Fotoğraf Koleksiyonu.

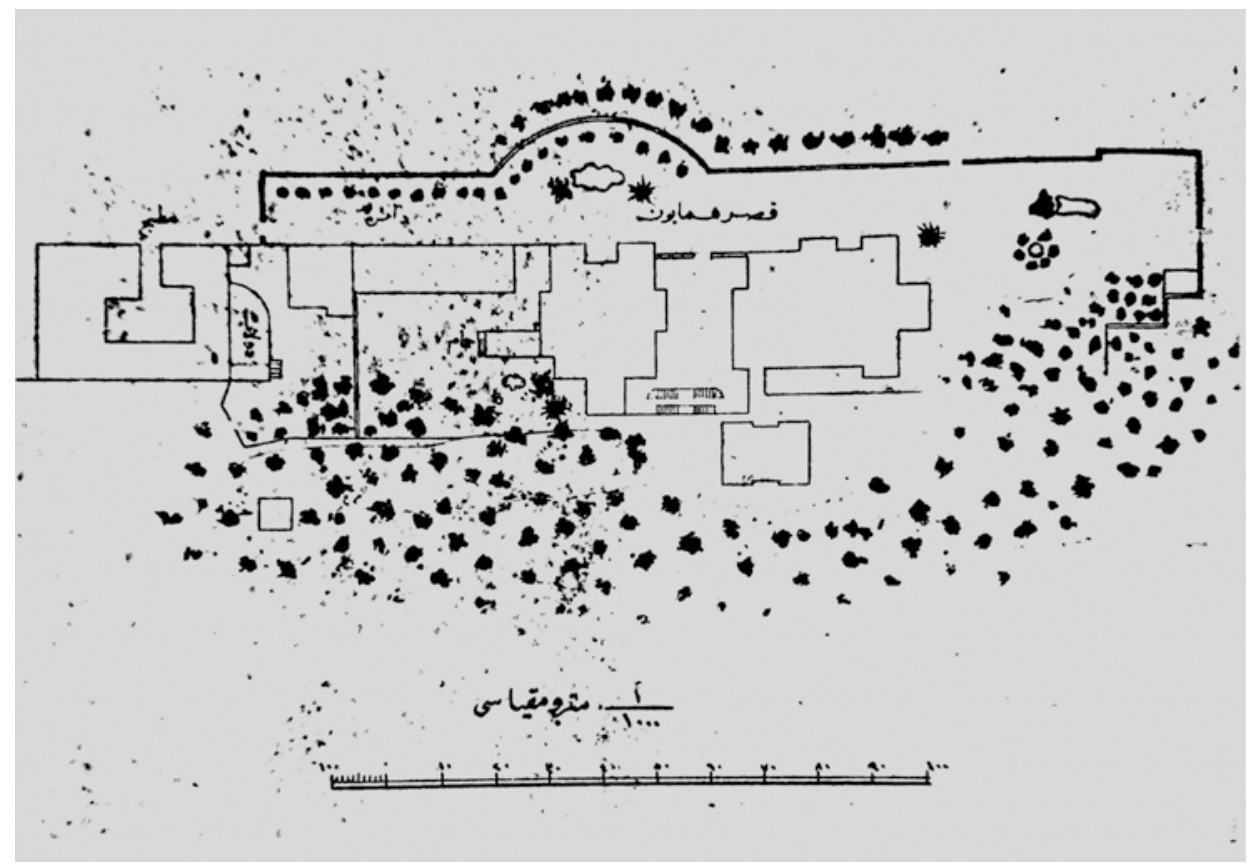

Şekil 7 Kâs̆ıthane Kasrı Hümayunu, 1886. Eldem, 1977. 


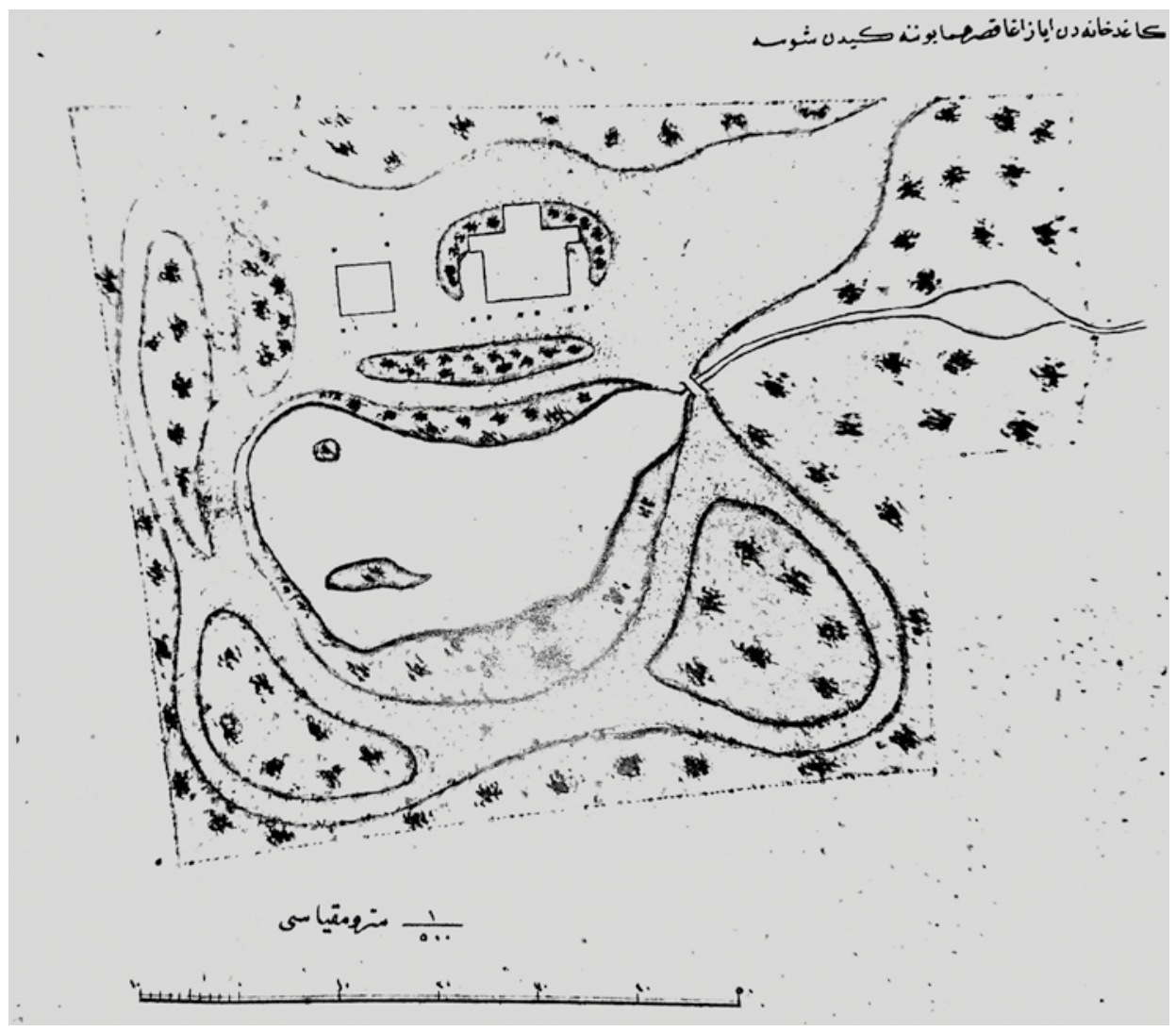

Şekil 8 Koşu Köşkü, 1886. Eldem, 1977.

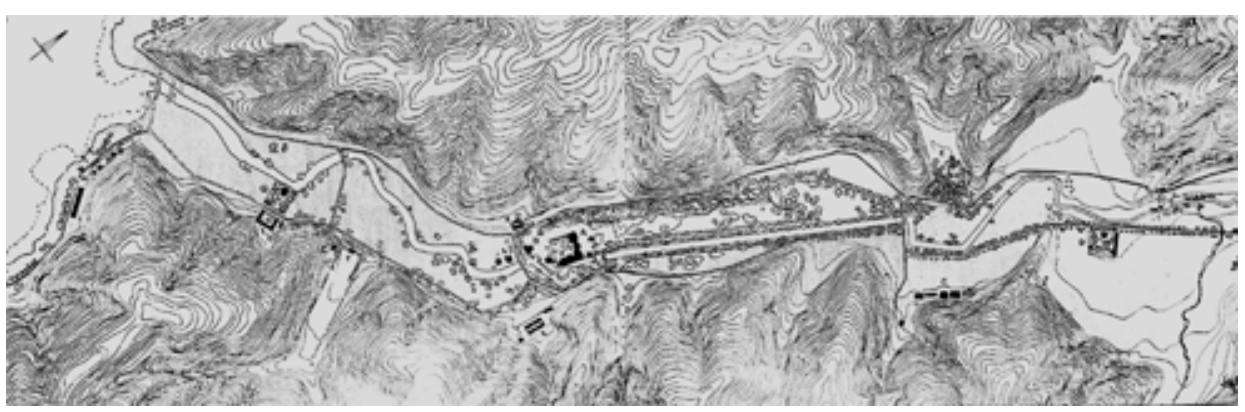

Şekil 9 Kâğıthane'nin XIX. yüzyıl sonlarındaki durumu. Eldem, 1977.

19. yüzyılda Kâğıthane Köyü ise camisi, sıbyan mektebi ve bağlı haneleriyle küçük bir köydür. 1844 tarihli iki ayrı nüfus defterine kayıtlı toplamda 122 Müslüman bulunmaktadır. Müslümanların 27’si Kıpti (Çingene) olup tamamı kündecilik (marangozluk) yapmaktadır. ${ }^{45}$ Aralarında Kasr-ı Hümayun bekçisi ve köy muhtarının da bulunduğu geriye kalan 95 kişinin büyük bölümü rençperdir. Bölgede tespit edilebilen diğer meslekler ise kahvecilik, arabacllık, koruculuktur. ${ }^{46}$ Üçüncü bir nüfus defterine göre bölgede 86 gayrimüslim yer almaktadır. Tamamı bahçıvan (bostancı) olan bu kişilerin Kâğıthane Köyü ve civarındaki bostanlarda çalıştığı anlaşılmaktadır. ${ }^{47}$ 
Küçük bir köy olarak mütevazı bir başlangıç yapan Kâğıthane bölgesi, 15. yüzyıldan itibaren saray eğlencelerinin yapıldığı bir dinlenme ve mesire yeri olarak karşımıza çıkmaktadır. Bu işlevini uzunca bir süre sürdüren bölgede, 19. yüzyılın sonlarında inşa edilen topçu okulu ve poligon sahalarıyla beraber sayfiye işlevinin yanı sıra bir takım askeri faaliyetler de gerçekleştirilmiştir. Öte yandan bölgenin sanayileşme faaliyetlerinden etkilenmediği görülmektedir.

\section{Alibey Deresi ve Yakın Çevresi}

Antik dönemdeki adı Kydaros olan Alibey Deresi'nin kıyısında kurulan köy fetihten sonra Fatih Sultan Mehmed'in uç beylerinden Ali Bey'in buraya yerleştirilmesiyle Alibey Köyü olarak adlandırılmıştır. 1498 tarihli Osmanlı kayıtlarında köy nüfusunun 46 kişi olduğu yazılıdır. Bunlar Alibey Çiftliği'nin personeli olup bir kısmı toprağı işleyen Müslümanlardır. Bu dönemde Osmanlı askerlerinin atlarının beslenmesi için ayrılan arazide Alibey Çiftliği dışında yerleşim görülmemiştir. 17. yüzyılda Evliyâ Çelebi’nin kırk haneli bir köy olarak kaydettiği Alibey Köyü yakınlarında IV. Mehmed'in bir av köşkü yaptırdığı bilinmektedir. ${ }^{48}$ IV. Mehmed'in tahttan indirilmesiyle bir süre metruk kalan köşk kullanılamaz hale gelmiştir. 18. yüzyılda bir mesire yeri olarak gelişen Alibey Köyü’nde, III. Ahmet Dönemi’nde üç büyük havuz yapılmış ve 1722 yılında bir kasır inşa edilmiştir. Burası Râşid tarafından Hüsrevâbâd olarak adlandırmıştı. ${ }^{49}$ Balıkhane Nazırı Ali Rıza Bey'in aktardığına göre İstanbul'un varlıklı aileleri mesire için kalabalık olan Kâğıthane yerine Alibey Deresi ve Çobançeşme yakınlarını tercih ederlerdi. ${ }^{50} 1730$ yılında Patrona Halil İsyanı sırasında tahrip olan kasır tekrar tamir edilmemiştir.

Alibey Köyü ile Haliç arasındaki bölge 19. yüzyıla kadar çiftlik ve miri arazi olarak kullanılmaya devam etmiştir. 19. yüzyıla gelindiğinde II. Mahmud'un kızı Adile Sultan’ın burada bir saray inşa ettirdiği ve burayı yazlık olarak kullandığı bilinmektedir. 1868 tarihli bir belgeye göre Silahtarağa yakınlarındaki Mehmet Ali Paşa'ya ait olan çiftlik ve arazi Adile Sultan’a devredilmiştir. ${ }^{51}$ 1906 yllına ait olan bir başka belgede Adile Sultan Köşkü'nün tamir edilmesine dair bir karar çıkarılmıştır. ${ }^{52}$ Dolayısıyla köşkün 20. yüzyıl başında hâlâ ayakta olduğu anlaşılmaktadır. Köşkün konumu söz konusu döneme ait haritalardan tespit edilebilmektedir.

Bizans Dönemi’nden itibaren Alibey Deresi’nin taşıdığı çamurun çömlek ve tuğla yapımında kullanıldığı, özellikle Eyüp kıyılarında buradan çıkarılan çamurla çömlekçilik yapıldığı bilinmektedir. $\mathrm{Bu}$ bölgede tuğla harmanlarının yer aldığı çeşitli dönemlerdeki haritalardan takip edilmektedir. 1880'lere gelindiğinde bölgede hâlihazırda var olan potansiyelin değerlendirildiği ve Çobançeşme yakınlarında bir tuğla fabrikası kurulduğu anlaşılmaktadır. 1884 tarihli bir masraf defterine göre İstanbul'da devlet adına tuğla üretmek üzere kurulmuş üç fabrikadan biridir.53 Osmanlı arşiv belgelerine göre Darüssaade Ağası Hafız Behram Ağa tarafından inşa edilmiştir. Kesin yapım tarihi bilinmemektedir. ${ }^{54}$ Hafız Behram Ağa’nın 1888 yılındaki ölümünden sonra fabrika, padişah

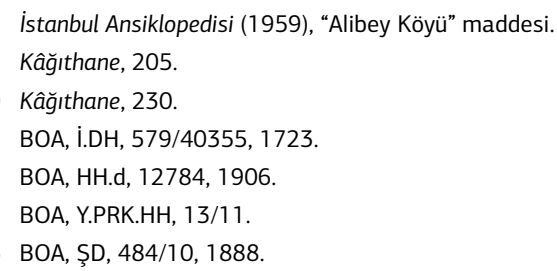


iradesiyle Bahriye Nezareti’ne devredilmiștir. ${ }^{55} 1899$ yllında fabrikanın genişletilmesine ilișkin bir belgede fabrikanın mevcut durumu ve fabrikaya dâhil edilebilecek alanların gösterildiği bir harita bulunmaktadır (şek. 10). ${ }^{56}$

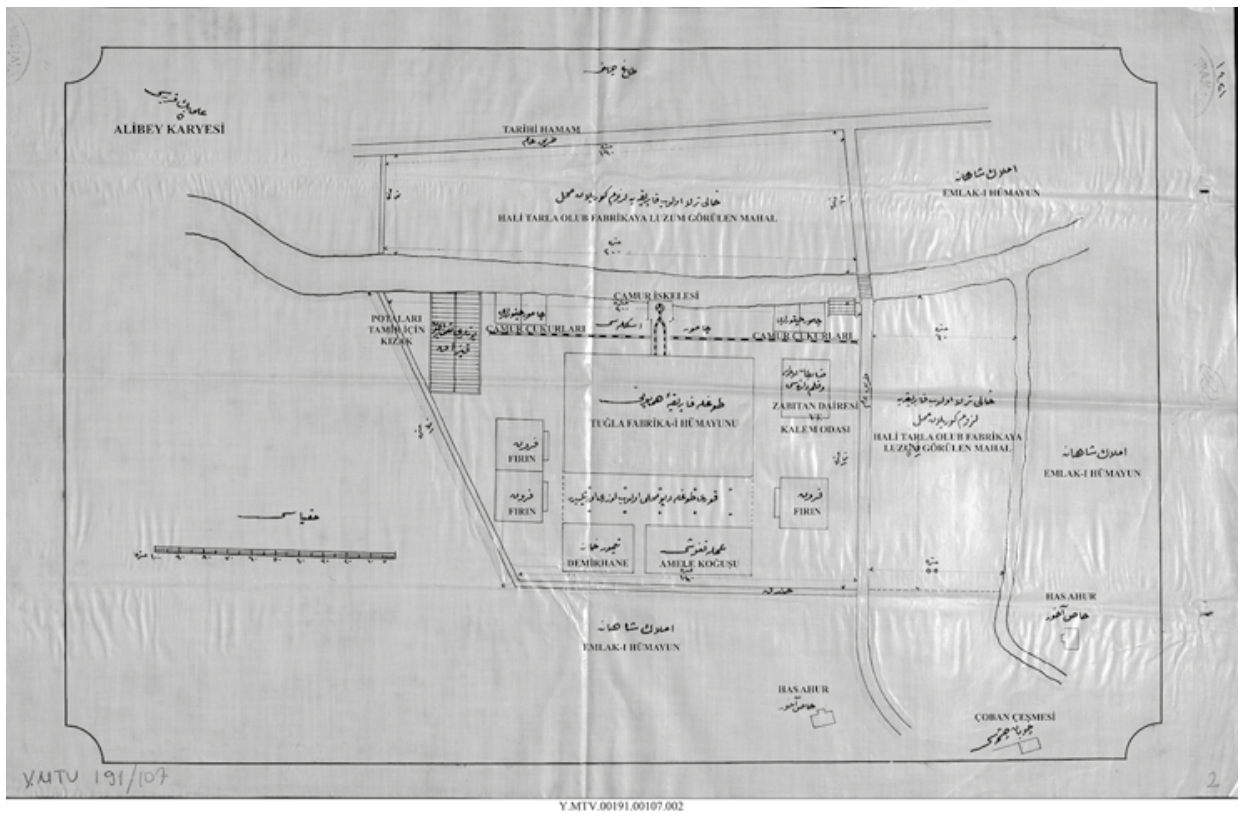

Şekil 10 Çobançeşme Tuğla Fabrikası, 1899. Başbakanlık Osmanlı Arşivi. Transkripsiyon yazar tarafından yapılmıştır.

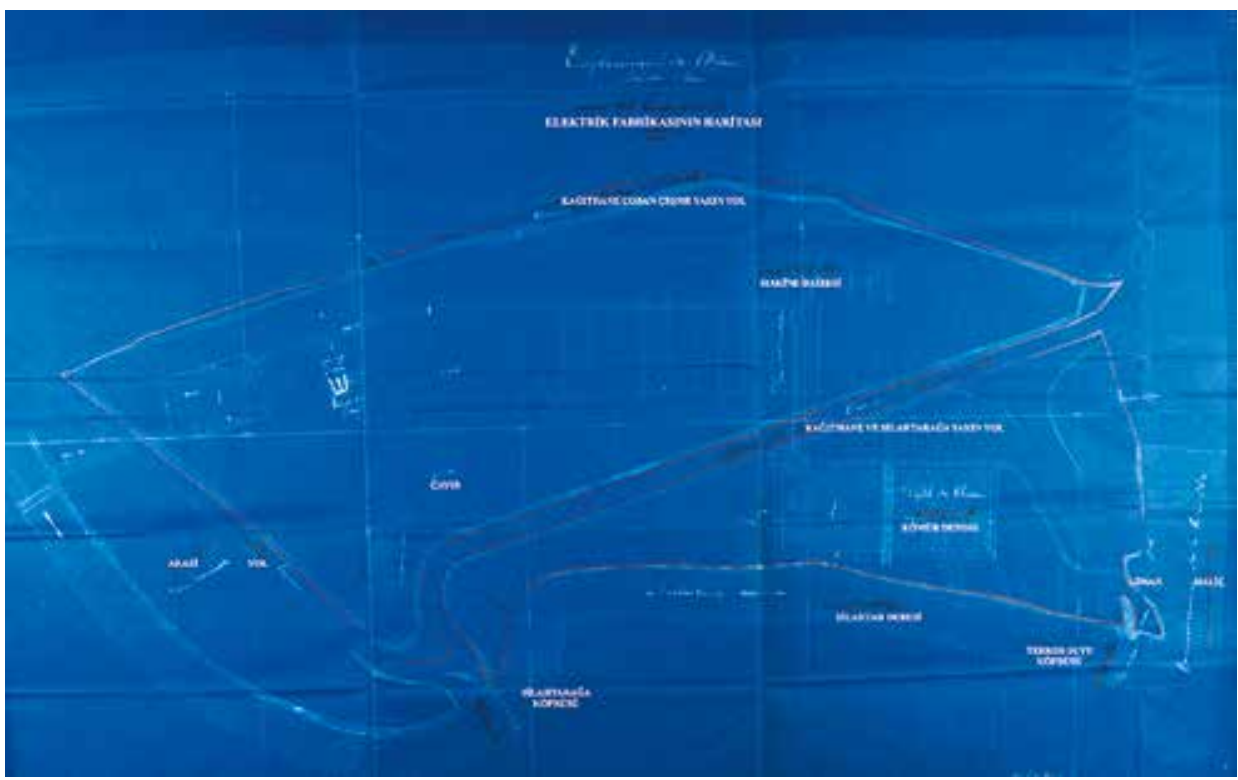

Şekil 11 Silahtarağa Elektrik Santrali ve çeuresi, 1911. Başbakanlık Osmanlı Arşivi. Transkripsiyon yazar tarafından yapıımıştır.

Devlet eliyle Alibey Köyü yakınlarında kurulan diğer önemli tesis ise Silahtarağa'daki Elektrik Santrali'dir. 20. yüzyıl başında alınan bir karar ile kente buhar gücüyle elektrik üreten bir enerji

55 BOA, ŞD, 484/10.

56 BOA, Y.MTV, 191/107, 1899 
tesisinin kurulması istenmiş ve konum olarak deniz yoluyla kömür naklinin mümkün olduğu Silahtarağa bölgesi seçilmiştir (şek. 11). ${ }^{57} 1913$ yılında tamamlanan tesis Macar Ganz Elektrik Anonim Şirketi tarafından kurulmuştur. Silahtarağa Elektrik Santrali'nin açılmasından sonra, sanayi tesislerinin birçoğu söz konusu santrale yakın olarak kurulmak istenmiştit. Fazla elektrik kullanan bu tesisler, Silahtarağa'dan direkt hat alarak yüksek voltajlı elektrikle çalışma imkânından faydalanmışlardır.58

19. yüzyllda Alibey Köyü ise küçük bir Müslüman yerleşmesiydi. 1844 tarihli nüfus defterlerine göre, bölgede 65 kişi yaşamaktadır. ${ }^{59} \mathrm{Bu}$ kayıtlar sadece erkek nüfusu göstermektedir. Dolayısıyla köyün yaklaşık 65 haneli olduğunu söylemek yanlış olmaz. Köyde yaşayan kişilerin önemli bir bölümü yoğurtçuluk yapmaktadır. Haritalardan ve bazı gezginlerin aktarımlarından bölgede çok sayıda mandıra olduğu bilinmektedir. Bölgede rastlanan diğer mesleklerden bazıları ise duhancllık (tütüncülük), semercilik, fırıncıllktır. ${ }^{60}$

18. yüzyıl ve öncesinde miri arazi ve mesire yeri olan Alibey Köyü, etrafında otlaklar ve mandıraların olduğu küçük bir köy olma özelliğini koruyordu. Eyüp’ten Alibey Köyü’ne kadar olan alanda Adile Sultan Köşkü dışında pek yapı bulunmuyor ve burası halen sayfiye işlevini sürdürüyordu. 19. yüzyıldan itibaren Alibey Deresi çevresinin sanayileşme faaliyetlerinden etkilendiği görülmektedir. Burada çeşitli fabrikaların kurulması, bölgenin dokusunu değiștirmiş ve sanayileşme ile beraber bölgenin mesire özelliği yok olmaya başlamıştır.

\section{Değerlendirme}

Antik dönemlerden beri varlık gösteren Alibey Köyü ve Kâğıthane Köyü yerleşimleri hem Bizans hem de Osmanlı Dönemi’nde kent içindeki önemli bölgelerdir. 18. yüzyılda gerek saray halkı gerekse tebaa tarafından dinlenme ve mesire alanı olarak kullanılan bölgeler, bu tarihten itibaren bir takım inşa faaliyetlerine tanık olmuşlardır.

Kâğıthane Köyü 16. yüzyıldan beri saray halkının tercih ettiği düğün ve eğlencelerde kullanılan ve buna bağlı olarak çeşitli yapıların inşa edildiği bir bölge iken, Alibey Köyü’nün daha sakin bir dönem geçirdiği, bölgede çeşitli çiftlik arazileri ve çayırların yer aldığı görülmektedir. 18. yüzyılda Lale Devri ile beraber Kâğıthane bölgesinin önemi artmıştır. Burada farklı zamanlarda çeşitli köşk ve sarayların inşa edildiği görülmektedir. Öte yandan Alibey Köyü yakınlarının hâlâ var olan işlevini sürdürdüğü ve Kâğıthane’ye göre daha az tercih edildiği söylenebilir. Kâğıthane bölgesinin tercih edilmesinde coğrafi özelliklerin etkili olduğu düşünülebilir. Alibey Deresi’ne kıyasla çevresinde daha geniş düzlüklerin yer aldığı Kâğıthane Deresi kıyılarının, dere yatağının düzenlenmesi konusunda kolaylık sağlayan fiziksel özelliklere sahip olduğu söylenebilir. Dolayısıyla Cetvel-i Sim adı verilen ve bir takım su oyunlarının yapıldığı düzenlemenin daha uzun bir bölgeye yayılması sağlanmış ve çevresinde köşk ve kasırların inşası için daha geniş alanlar sunmuştur. Öte yandan 16. yüzyıldan beri hasbahçe olarak kullanılan Kâğıthane bölgesinde hâlihazırda var olan sayfiye işlevinin sürdürülmesi bir alışkanlığın sonucu olabilir.

57 BOA, İ.MMS, 140/16, 1911.

58 Köksal, “i̇stanbul'daki Endüstri Mirası,” 44.

59 BOA, NFS.d, 159. 1882 yılına kadar gerçekleştirilen nüfus sayımları sadece erkek nüfusun tespitine yöneliktir.

60 BOA, NFS.d, 159. 


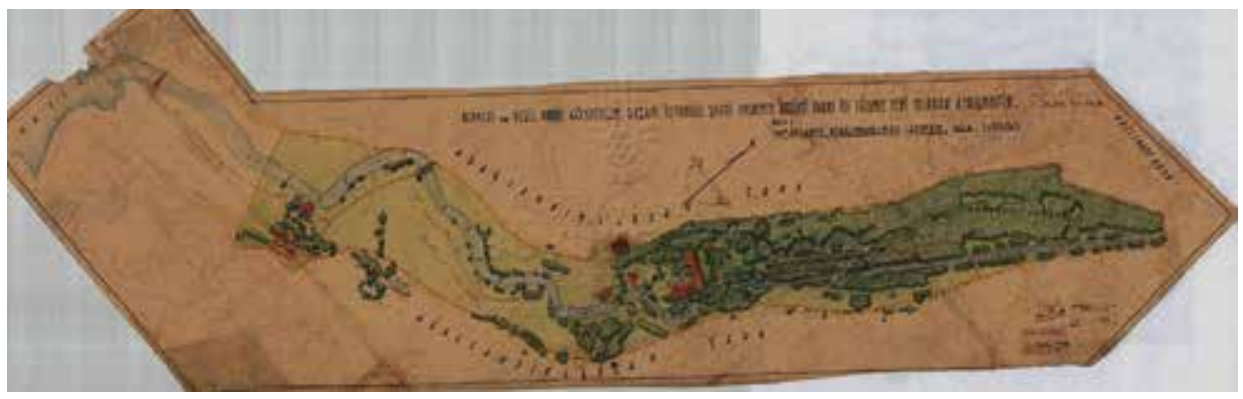

19. yüzyıla gelindiğinde hem Kâğıthane hem de Alibey köylerinin yakınlarında bir takım yeni işlevler görülmektedir. 19. yüzyılda Osmanlı Devleti’nin yoğunlukla sürdürdüğü sanayileşme faaliyetleri özellikle Haliç kıyılarında büyük dönüşümlere neden olmuş ve buralarda çok sayıda fabrika inşa edilmiştir. 19. yüzyıla kadar Kasımpaşa ve çevresinde görülen sanayi faaliyetleri kısa zamanda tüm kıyıya yayılmıştır. Bu faaliyetler Alibey Deresi çevresine de ulaşmış, bölgede var olan mesire yeri, çiftlik ve miri arazilerin yanı sıra sanayi tesisleri de görülmeye başlanmıştır. Kâğıthane bölgesi bu dönüşümden en az etkilenen bölgelerden biridir. Bölgede büyük sanayi tesisleri kurulmamış, Haliç kıyılarındaki dönüşüm bu bölgeyi etkilememiştir. Padişahların ve halkın hâlâ sıkça ziyaret ettiği bölgenin çevre dokusunu koruduğu söylenebilir. 20. yüzyılda da Kâğıthane bölgesinin mesire alanı olarak planlandığı 1940 tarihli H. Prost imzalı plandan anlaşılmaktadır (şek. 12). Dolayısıyla Kâğıthane bölgesinde 15. yüzyıldan beri süre gelen bir işlevsel süreklilikten bahsetmek mümkündür. Kâğıthane’ye nazaran Alibey Köyü kıyılarının sanayileşme için tercih edilme sebeplerinden biri doğal sınırlarını koruyan dere yatağı olabilir. Böylelikle kurulacak olan sanayi tesisleri için hem taşımacılık hem de atıkların uzaklaştırılması konusunda bir potansiyel sunmaktadır. Alibey Deresi’nden itibaren Alibey Köyü’ne kadar olan bölge içinde, bir fabrikanın yaydığı kirlilik ve atıklardan etkilenebilecek bir yerleşimin olmamasının da bölgeyi sanayi tesisi kurmak için cazip hale getirdiği düşünülebilir. Dahası bölgedeki yapı stokunun nicelik olarak azlığı sanayi tesislerinin inşası için potansiyel boş alanlar sunmaktadır. Patrona Halil İsyanı sırasında tahrip olan Hüsrevâbâd Kasrı ve çevresi tekrar inşa edilmemiştir. Dolayısıyla bölgede 19. yüzyılda inşa edilen Adile Sultan Kasrı ve çevresindeki çiftlik dışında yapı bulunmamaktadır. 19. yüzyıla ait haritalardan da bölgede çiftlik ve mandıralardan başka yapılaşmanın olmadığı görülmektedir. Oysa yeniden düzenlenen ve çevresinde köşklerin yer aldığı Kâğıthane Deresi bir sanayi tesisinin atıklarının uzaklaştırılması konusunda son tercih olabilir. Kâğıthane Deresi kıyılarındaki mesire alanları 19. yüzyılda hâlâ saray halkı ve tebaa tarafından sıklıkla kullanılmaktadır. Söz konusu bölge devletin gücünün ve zenginliğinin sergilenmesi bakımından da önemli bir noktada yer almaktadır. Bölgedeki mimarinin yanı sıra burada düzenlenen şenlikler/eğlenceler de bu gücün temsiliyeti açısından önemlidir. Kaldı ki içinde bulunulan ekonomik şartlarda devletin hâlihazırda varlığını sürdüren ve maliyeti yüksek yapıların yer aldığı bölgeyi sanayiye terk edip başka bir sayfiye yeri kuracak gücü olmayabilir. Kentin dört bir yanında inşa edilen prestij yapıları, saraylar, okullar ve meydan çeşmelerinin ekonomik imkânları zorladığı bilinmektedir.

Son olarak Haliç kıyılarında görülen yoğun sanayileşmenin Alibeyköy bölgesinde bu kadar etkili olmadığı söylenebilir. Ayvansaray, Fener, Balat gibi bölgelerin aksine Alibeyköy sanayinin yanında var olan işlevini sürdürmeye devam etmiştir. Bu bölgelerde demografik bir değişimden bahsetmek de söz konusu değildir. Hem Kâğıthane Köyü hem de Alibey Köyü küçük birer köy olma özelliklerini korumaya devam etmiş, bölgedeki meslekler de 19. yüzyll boyunca sürdürülmeye devam etmiştir. 
Kaynakça

Başbakanlık Osmanlı Arşivi [BOA], AE.SMHD.I, 33/1970, 1728.

BOA, C.AS, 49992, 1772.

BOA, C.BLD, 21/1018, 1723.

BOA, C.SM, 135/6775, 1723.

BOA, HH.d, 12784, 1906.

BOA, I.DH, 579/40355, 1723.

BOA, IE.DH, 35/3062, 1723.

BOA, I.MMS, 140/16, 1911.

BOA, NFS.d, 159.

BOA, NFS.d, 159, 1844.

BOA, NFS.d, 214, 1844

BOA, NFS.d, 369, 1844.

BOA, ŞD, 484/10.

BOA, ŞD, 484/10, 1888.

BOA, Y.MTV, 191/107, 1899.

BOA, Y.PRK.HH, 6/29, 1884.

BOA, Y.PRK.HH, 13/11.

Çelik, Zeynep. 19. Yüzyılda Osmanlı Başkenti Değişen Istanbul. Çeviren Selim Deringil. İstanbul: Türkiye İş Bankası Kültür Yayınları, 2015.

Dionysios Byzantios. Boğaziçinde Bir Gezinti. Çeviren Mehmet Fatih Yavuz. İstanbul: Yapı Kredi Yayınları, 2010.

Eldem, Sedad Hakkı. Sa'dabad. Ankara: Kültür Bakanlığı, 1977.

Evliyâ Çelebi. Günümüz Türkçesiyle Evliyâ Çelebi Seyahatnâmesi: Istanbul. C. 1, ktp. 1. Hazırlayanlar Seyit Ali Kahraman ve Yücel Dağlı. İstanbul: Yapı Kredi Yayınları, 2003.

Evliyâ Çelebi. Günümüz Türkçesiyle Evliyâ Çelebi Seyahatnâmesi: İstanbul. C. 1, ktp. 2. Hazırlayanlar Seyit Ali Kahraman ve Yücel Dağlı. İstanbul: Yapı Kredi Yayınları, 2003.

Giz, Adnan. “Türkiye'de İlk Buhar Makineleri.” Istanbul Sanayi Odası Dergisi, s. 57 (Kasım 1970): 6-7.

Hovhannesyan, Sarkis Sarraf. Payitaht Istanbul'un Tarihçesi. Çeviren Elmon Hançer. İstanbul: Tarih Vakfı
Yurt Yayınları, 1997.

Illk Çağdan Günümüze Kâğıthane. C. 2. Hazırlayan Hüseyin Irmak. İstanbul: Kâğıthane Belediyesi, 2018.

Koçu, Reşad Ekrem. “Bostancıbaşı Defterleri." istanbul Enstitüsü Mecmuası, s. 4 (1958): 39-90.

Köksal, T. Gül. “İstanbul'daki Endüstri Mirası için Koruma ve Yeniden Kullanım Önerileri." Yayımlanmamış Doktora Tezi, İstanbul Teknik Üniversitesi, 2005.

Kömürciyan, Eremya Çelebi. İstanbul Tarihi: XVII. Asırda İstanbul. Çeviren Hrand D. Andreasyan. 2. bas. İstanbul: Eren Yayıncılık ve Kitapçılık, 1988.

Mantran, Robert. 17. Yüzyılın Ikinci Yarısında İstanbul: Kurumsal, Iktisadi, Toplumsal Tarih Denemesi. C. 2. Çevirenler Mehmet Ali Kılıçbay ve Enver Özcan. Ankara: Türk Tarih Kurumu, 1990.

Müller-Wiener, Wolfgang. Bizans'tan Osmanliya İstanbul Limanı. Çeviren Erol Özbek. İstanbul: Tarih Vakfı Yurt Yayınları, 1998.

Osmanlı Sanayii 1913, 1915 Yılları Sanayi İstatistiki. Hazırlayan A. Gündüz Ökçün. Ankara: T.C. Başbakanlık Devlet İstatistik Enstitüsü, 1997.

SALT Araştırma. “Journal de Constantinople.” Erişim Tarihi: 24 Temmuz 2021. https://archives.saltresearch. org/handle/123456789/129385.

Seyahatnamelerde Kâğıthane. Hazırlayanlar Hüseyin Irmak ve Rıfat Behar. Çeviren Mario Veris. İstanbul: Kâğıthane Belediyesi, 2019.

Uzunçarşılı, İsmail Hakkı. Osmanlı Devletinin Merkez ve Bahriye Teşkilâtı. 3. bas. Ankara: Türk Tarih Kurumu, 1988.

Yaşar, Kübra. "19. Yüzyılda Bır Halıç Yerleşımı Olarak Ayvansaray.” Yüksek Lisans Tezi, İstanbul Teknik Üniversitesi, 2017.

Yılmaz, Gülin Işık. "Haliç Kıyı Şeridinde Sanayileşme ile Ortaya Çıkan Kentsel Dönüşüm.” Doktora Tezi, Yıldız Teknik Üniversitesi, 2008. 